\title{
1.6 Переваги використання сталефібробетону в дорожньому будівництві
}

Успішний розвиток будівельної галузі базується на використанні сучасних технологій та матеріалів, які повинні відповідати нормам стандартизації $[69,70]$.

За статистикою, бетонне покриття дорожче асфальтового в 1,5-2 рази, тобто приблизно на 70-80\%. Асфальтове вимагає догляду і ремонту вже через 34 роки після введення дороги в експлуатацію: заливання тріщин, засипки ям і т. п. Бетонне покриття перші 10-12 років експлуатації практично нічого не вимагає ніяких капіталовкладень. Фактично через вісім років загальні експлуатаційні витрати на бетонну i асфальтову дороги зрівнюються, після цього періоду бетонна дорога стає дешевшою.

Згідно з даними ДП «Державний дорожній НДІ», що входить в структуру «Укравтодору», вартість 1 кв. м покриття 3 цементобетону майже така ж, як i вартість покриття з асфальтобетону - 1422 i 1466 грн. Але це середній показник для всіх категорій доріг в Україні. Наприклад, «одягати» в тверде покриття дороги I категорії набагато дешевше, ніж в асфальтобетон - економія, згідно 3 даними будівельної корпорації «Альтіс», може досягати 30\%. Відповідно до прийнятих нормативів, дорогам із асфальтобетонним покриттям необхідний поточний ремонт через шість років, через 12 - середній поточний ремонт, i на 15-му році — капітальний [71].

За даними ДП ДерждорНДІ, мінімальний міжремонтний термін для доріг 3 цементобетонним покриттям - дев’ять років. На обслуговування і будівництво 1 км дороги з твердим покриттям витрачається на 5\% менше матеріалів, ніж на обслуговування кілометра дороги з м’яким покриттям. Однак витрати на оплату праці, на будівництво і обслуговування кілометра ЦБД майже в три рази вищі, ніж для доріг з асфальтобетону. В загальній структурі вартості витрати на оплату праці незначні - займають менше 1,5\% [72].

Міністерство інфраструктури планує будівництво кількох бетонних доріг - від Миколаєва до Кропивницького, а також траси, що з’єднають Миколаїв, Херсон та Одесу. 
Дороги з цементобетонного покриття вважаються більш безпечними для водія. Асфальт поглинає світло, дорогу з цементобетону краще видно в нічний час доби. Крім цього, у такого покриття краще зчеплення з гумою, тому гальмівний шлях у автомобіля — коротший [72].

Для дорожнього будівництва використовують цемент М400. «Це цемент 3 міцністю 400 мегапаскалів. I всі великі виробники в Україні давно випускають такий цемент. Тож навіть якщо в Україні почнуть щороку будувати по 3000 км ЦБД, заводи зможуть забезпечити будівельників сировиною

В Україні довжина швидкісних магістралей - 280 км. Тоді як у сусідній Польщі - 1,5 тис. км. У Німеччині - 13 тис. В Іспанії - 15 тис. км. Українські дороги у поганому стані. Країна займає низькі позиції у рейтингах автомобільних шляхів.

Плюси бетонних доріг. Будівництво бетонних доріг дорожче, ніж асфальтобетонних. Але їхня експлуатація обходиться дешевше. Витрати на будівництво і експлуатацію зрівняються протягом 10 років.Такі дороги рідше ремонтують. Цемент не деформується у спеку під впливом вантажного транспорту. Гальмівний шлях на цементобетонних дорогах коротший. Краща видимість вночі [73].

Щоб змінити ситуацію та покращити українські дороги, слід усвідомити три важливих моменти:

— для відновлення всієї мережі доріг потрібно боротися за довговічність понад 15 років;

- потрібно використовувати ті технології, які працювали б на благо української економіки та добробуту громадян;

— необхідно мати незалежний контроль якості робіт з будівництва доріг.

В Україні лише 1\% цементобетонних доріг. Приблизно 60-70\% нових доріг, які сьогодні проектують у країнах $Є \mathrm{C}$, — цементобетонні. Такі показники - серйозний сигнал замислитися над тим, чому така практика не впроваджена в Україні. 
Український інститут майбутнього та асоціація "Укрцемент" провели економічну оцінку цементобетонних доріг i отримали низку грунтовних результатів.

По-перше, вартість цеементобетонних доріг виявилася на рівні вартості асфальтобетонних чи й нижчою. Оскільки життєвий цикл автомобільних доріг для бетонної дороги - 20-25 років, а для асфальту — до 10 років. Загальна вартість цементобетонних доріг протягом 20 років на 40\% і більше нижча, порівняно з вартістю асфальтобетонних.

По-друге, понад $50 \%$ вартості асфальтобетонних доріг становить імпортний бітум. Відповідно, при будівництві доріг знижується показник "чистого експорту" у структурі ВВП. Оскільки бітум є продуктом нафтопереробки, вартість будівництва доріг з асфальтобетону прямо залежатиме від світових цін на нафту та інших ризиків, пов'язаних з імпортом.

Тим часом будівництво цементних доріг повністю забезпечується сировиною, виробленою в Україні.

По-третє, запас виробничих потужностей цементної промисловості становить понад 30\%, що дає змогу забезпечити будівництво цементобетонних доріг в Україні. А головне - ми можемо повністю забезпечити українськими матеріалами будівництво автомобільних доріг на основі цементобетону.

Розрахунки інституту свідчать, що будівництво бетонних доріг буде вигідним і державі, і платникам податків, Це може стати пріоритетом у розвитку дорожнього господарства. Дасть можливість:

— підвищити привабливість транзиту нашої держави;

- збільшити ВВП та інвестиції;

— замінити імпорт місцевим виробництвом;

— вирішити соціальну проблему забезпечення робочими місцями [73].

Вперше сталофібробетон в якості матеріалу був використаний для ремонту дорожніх покриттів в США. Завдяки своїй високій міцності, опору втомі, можливості укладання досить тонкими шарами, сталефібробетон володіє очевидними перевагами. Починаючи з 1972 року в США були здійснені досить 
великі проекти в цьому напрямку, що включають влаштування покриттів міжміських шосе, міських вулиць, площадок для стоянок автомобілів (штати Мічиган, Айова, Міннесота). Довжина ділянки покриття дороги в штат Айова становила 8 км при ширині проїзної частини 6,7 м. Вміст сталевих фібр в покритті змінювався на різних ділянках дороги від 0,75 до 1,5 \% за об'ємом. У штаті Міннесота в якості армуючих компонентів були застосовані відрізки сталевого дроту та скляні волокна. Товщина покриття варіювалась в межах від 51 до 102 мм [74, 75, 76, 77].

У аеропорту Мак Карен в м. Лас-Вегас (США) споруджена стоянка для літаків. Її площа 7300 кв.м, вона призначена для літаків 3 великою масою. Аналогічні покриття для стернових доріжок, злітних посадочних смуг є в Міжнародному аеропорту м. Тампа (США), Седар Репіндз (США), Джона Кенеді (США) і інших . На аеродромі в м. Лас-Вегас площа укладеного СФБ 51400м2, товщина $15 \mathrm{~cm}$ замість $30 \mathrm{~cm}$ із звичайного бетону. Укладання вели серійними бетоноукладачами $[74,78]$.

На території Росії значний обсяг досліджень з вивчення експлуатаційних характеристик сталефібробетонних покриттів доріг був проведений в Алтайському краї. Зведення покриття здійснювалося за допомогою бетоновкладальних машин (БУМ) [79, 80]. Товщина перерізу покриття становила 12 см. Спостереження за покриттям з моменту його зведення в 1982 р. по 1998 р. показало, що його стан в жорстких кліматичних умовах Алтайського краю був досить стабільним, не вимав капітального ремонту і відновлення. У той же час, експлуатаційні пошкодження на сусідніх ділянках автодороги виникали в значній кількості. Був зроблений висновок про можливість і доцільність подальшого застосування сталефібробетону при зведенні автодоріг з високою інтенсивністю руху (першої та другої технічних категорій). Дослідно-виробничі роботи по зведенню ділянки дороги з сталефібробетону показали наступне.

Дослідити характеристики, переваги та доцільність використання високоефективних матеріалів як сталефібробетон при будівництві автомобільних доріг і аеродромів. 
В даній роботі виконано порівняльний аналіз трьох видів стальної фібри (різаної із листа, анкерної та хвильової), а також досліджено вплив технологічних параметрів на властивості сталефібробетону.

Результати досліджень. В сучасному будівництві все ширше застосовують фібробетон, для якого характерні підвищені значення міцності на розтяг, ударота вібростійкість, низька стираність та ряд інших покращених фізико-механічних властивостей $[81,82,83]$. Сталева фібра зазвичай виготовлена зі стального дроту довжиною від 30 до 80 мм, діаметром 0,5 - 1,2 мм, міцність при розтягу близько 1000 МПа і більше. Фібра може бути виготовлена 3 нержавіючої сталі, зі звичайної сталі з покриттям та без покриття. Бетонна матриця для всіх зразків виготовлялась із одного складу бетону $[84,85]$.

Кубову і призмову міцність визначались за стандартними методиками. На гідравлічному пресі П-250 у віці 28 діб при одноразовому монотонному навантаженні було встановлено, що призмова міцність бетону становить $=14,0$ МПа, а кубова міцність - = 17,07 МПа.

Спостерігаючи за характером руйнування бетонних зразків з фібровим армуванням та без нього, виникає закономірність, що зразки із фіброю руйнувалися плавніше і в'язко без втрати форми зразка. Зруйновані зразки тримають форму і для того щоб розглянути розташування фібри, приходилось до розбивати їх рис. 1. Можна зробити висновок, що в бетоні із фіброю відбувається перерозподіл зусиль як показано на рис. $2,3,4$. 


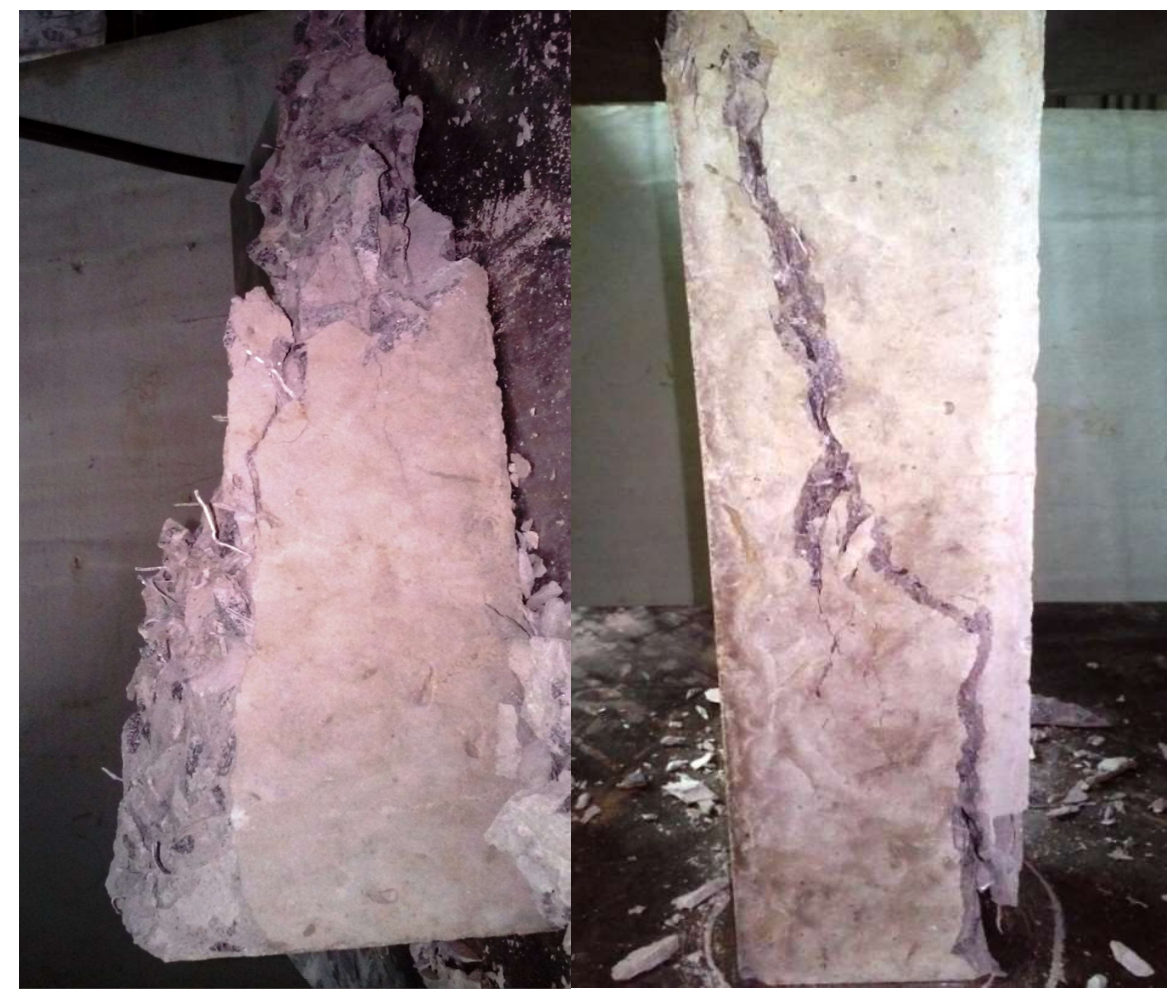

Рисунок 1 - Зруйнована призма із фібровим армуванням

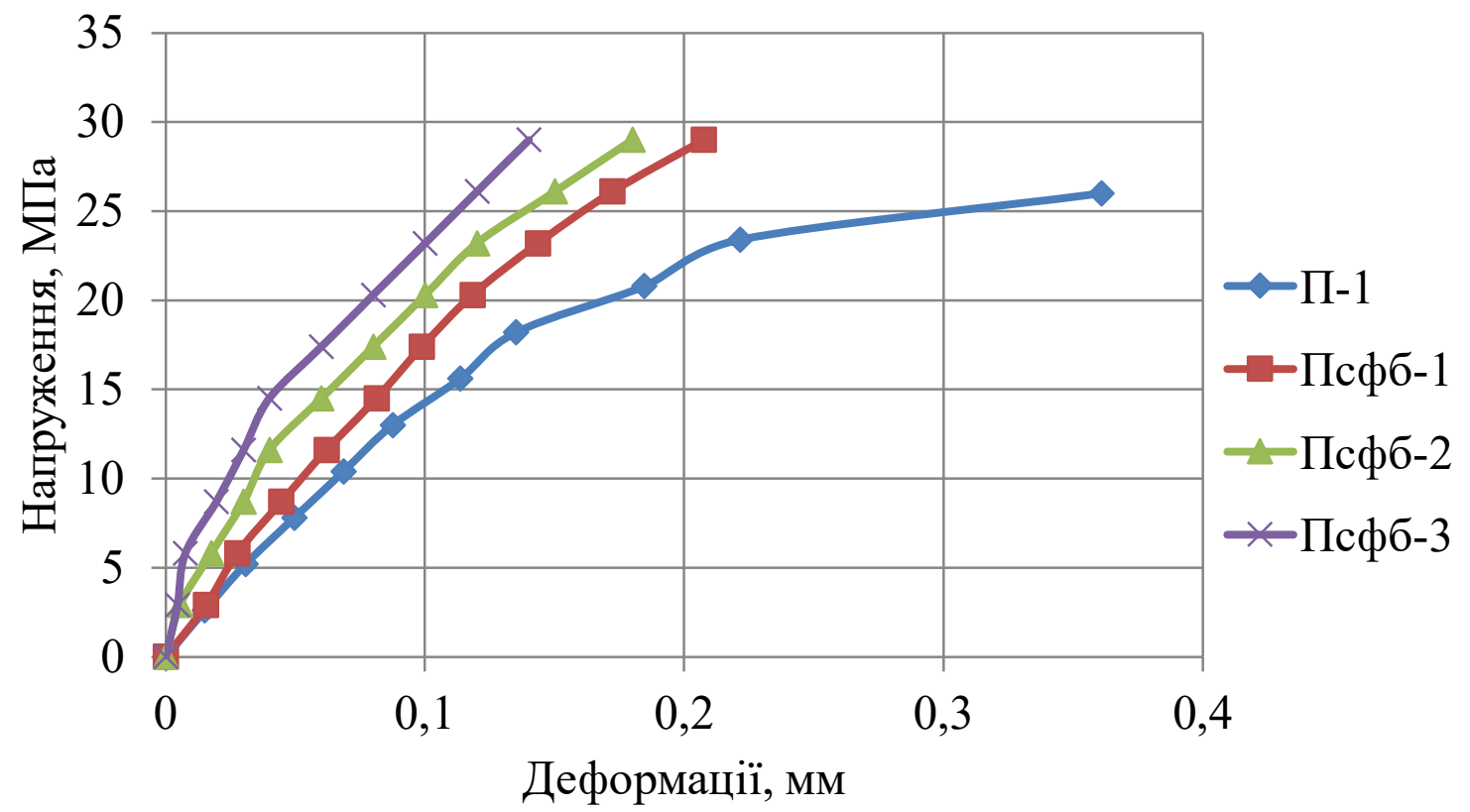

Рисунок 2 - Діаграма порівняння напруження-деформації бетонних зразків (1 серії) П-1 неармованого і зразків бетону армованого: фіброю різаною

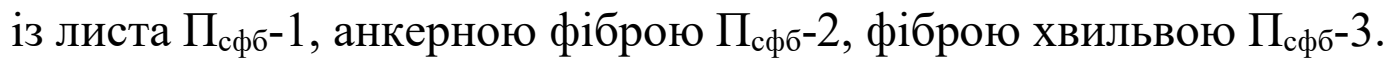




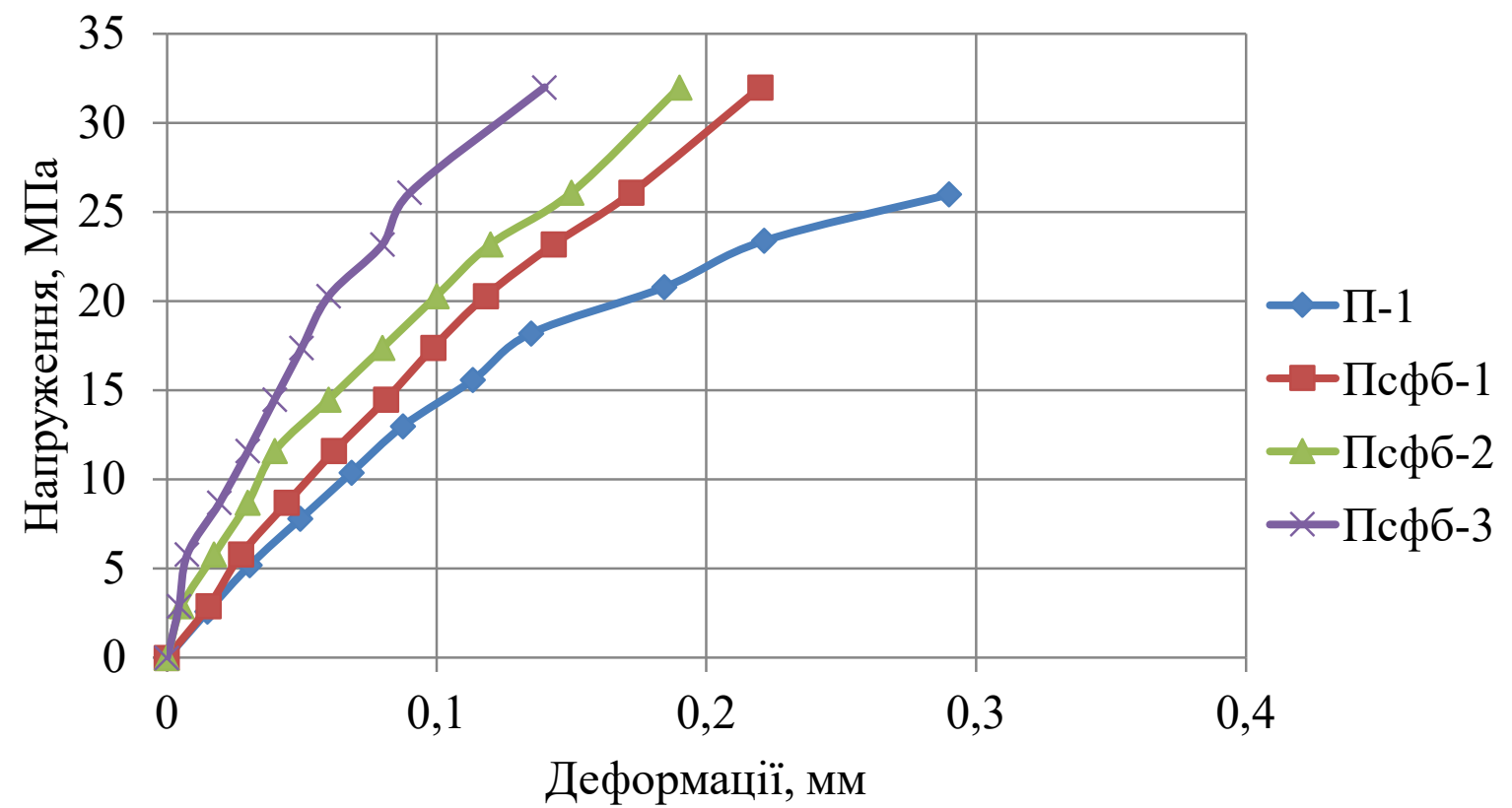

Рисунок 3 - Діаграма порівняння напруження-деформації бетонних зразків (2 серії) П-1 неармованого і зразків бетону армованого: фіброю різаною

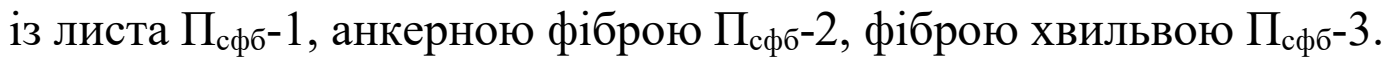

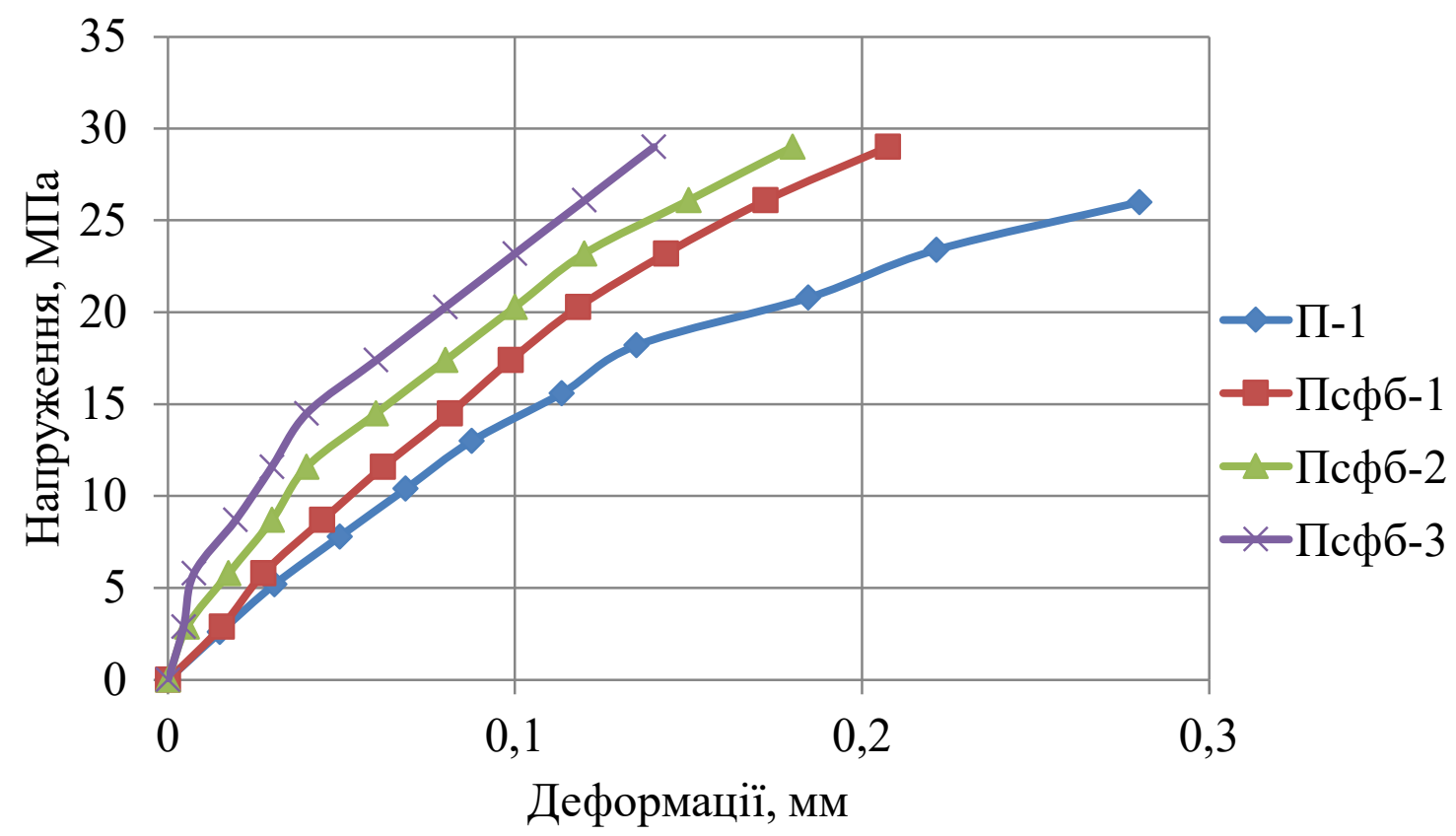

Рисунок 4 - Діаграма порівняння напруження-деформації бетонних зразків (3 серії) П-1 неармованого і зразків бетону армованого: фіброю різаною

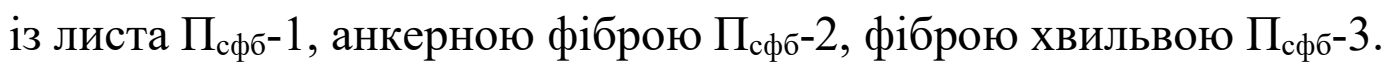


При будівництві ефективність застосування сталефібробетону досягається зниженням трудовитрат на арматурні роботи, суміщенням технологічних операцій під час приготування, армування, укладання та ущільнення сталефібробетонної суміші, продовження терміну експлуатації конструкцій і зниження витрат на різні види поточного ремонту [86].

Можна констатувати високу стабільність і довговічність СФБ покриття без ремонтів і відновлення. Таким чином, було встановлено, що застосування автобетонозмішувачів при зведенні монолітних конструкцій зі сталефібробетонну виявляється досить ефективним і може бути рекомендовано для широкої практики в дорожньому будівництві. У цьому випадку створюються передумови для скорочення кількості технологічних операцій і підвищується продуктивність праці на будівельному майданчику.

Висновки. За даними проведених досліджень можна зробити наступні висновки. Вироби із сталефібробетону характеризуються підвищеною міцністю. Застосування, для армування бетонів, сталевої фібри, дозволяє:

— знизити масу бетонних виробів;

— фібра різана із листа збільшує марочну міцність бетону в середньому до $15 \%$;

— фібра анкерна збільшує марочну міцність бетону в середньому до 20\%;

- фібра хвильова збільшує марочну міцність бетону в середньому до $25 \%$.

В результаті досліджень встановлено оптимальні шляхи збільшення міцності бетону на стиск шляхом введення до його складу дисперсної арматури у вигляді металевої.

За результатами досліджень були побудовані діаграми, які, в сукупності 3 комплексом отриманих експериментальних даних, можуть бути використані для проектування складів сталефібробетонів з комплексом заданих властивостей.. Додактовий ефект дисперсного армування на міцнісні властивості сталефібробетонів забезпечує, як показали експериментальні дослідження, орієнтація сталевої фібри. 
Особливістю фібробетонів є відсутність крихкого руйнування і розвиток значних деформацій при втраті ними несучої здатності. Тому для розразунку конструкцій важливим показником є залишкова міцність, що визначається за діаграмою "напруження - деформація".

На основі аналізу експериментальних характеристик сталефібробетонів встановлено ефективність застосування для дрібнозернистих бетонів хвилястої сталевої фібри, що має підвищену поверхню зчеплення з бетоном.

Доведено, що застосування хвилястої сталевої фібри дрібнозернистого бетону на досліджуваних видах фібри дозволяє найбільше підвищити міцність на стиск до 35\%. 